\title{
Recenzja
}

\section{Marta Derlatka, Skarga konstytucyjna wiemczech, Wydawnictwo Sejmowe, Warszawa 2009, ss. 357}

Nakładem Wydawnictwa Sejmowego w 2009 r. ukazała się publikacja Marty Derlatki poświęcona skardze konstytucyjnej w Republice Federalnej Niemiec. Zagadnienia niemieckiego konstytucjonalizmu, w tym sądownictwa konstytucyjnego, cieszą się w Polsce dużym zainteresowaniem i stanowią przedmiot wielu prac badawczych z zakresu nauk prawnych, ale i nauk społecznych. Dzieje się tak zapewne dlatego, że obecnie trudno sobie wyobrazić prowadzenie badań naukowych bez odniesienia do doświadczeń innych państw, zwłaszcza z perspektywy prób kształtowania jednolitych europejskich standardów ochrony praw człowieka. A ponadto doświadczenia niemieckie w zakresie kontroli konstytucyjności nie przestały być źródłem inspiracji dla innych państw europejskich, co uwidacznia się nie tylko w recepcji rozwiązań prawnych, ale znajduje swoje odzwierciedlenie w poglądach wyrażanych w orzecznictwie sądów europejskich. Także polski Trybunał Konstytucyjny w swoich orzeczeniach nawiązuje do kluczowych rozstrzygnięć Federalnego Trybunału Konstytucyjnego, jak choćby do wyroku z dnia 12 października 1993 r. w sprawie 2BvR 2134, 2159/92 Maastricht. Nie bez powodu też niemieckie sądownictwo konstytucyjne uchodzi za jedno z najsilniejszych w Europie.

W doktrynie, zarówno polskiej, jak i niemieckiej, podkreśla się niebagatelne znaczenie, jakie dla umocnienia pozycji Federalnego Trybunału Konstytucyjnego (FTK) i rozwoju praw podstawowych, wywarła instytucja skargi konstytucyjnej. Skarga konstytucyjna stała się centralnym polem działania niemieckiego strażnika Ustawy Zasadniczej. Stąd nie może dziwić zainteresowanie tą instytucją w piśmiennictwie polskim. Do tej pory jednak w literaturze polskiej ukazywano niemiecką skargę konstytucyjną, bądź w perspektywie prawnoporównawczej, bądź jako jedną z kompetencji FTK, natomiast odrębne jej opracowania miały formę artykułów naukowych bądź przyczynkarskich. Recenzowana praca stanowi zaś kompleksowe 
ujęcie tematu, zawierające szczegółową charakterystykę niemieckiej skargi oraz ukazuje kluczowe problemy z praktyki stosowania tej instytucji. Autorka poddaje wnikliwej analizie przepisy regulujące skargę, omawia najważniejsze orzeczenia dotyczące materii skargowej oraz w szerokim zakresie powołuje poglądy niemieckich konstytucjonalistów, wykorzystując przy tym liczne materiały źródłowe.

M. Derlatka nie poprzestaje na przedstawieniu funkcjonowania skargi niemieckiej, ale powołując się na krytyczne głosy pod adresem polskiej skargi, dokonuje w zakończeniu pracy syntetycznego porównania obu skarg, co ukazać ma wady i zalety znacząco różniących się od siebie rozwiązań. Ponadto, w książce czytelnik znajdzie informacje o działalności samego FTK (rozdział II, s. 253-266) oraz jego najważniejszych decyzjach, np. w sprawie ochrony życia (s. 91). Warto podkreślić, że nie jest to pierwsza publikacja Autorki dotycząca niemieckiej skargi konstytucyjnej. Równie interesującym studium poświęconym temu zagadnieniu jest artykuł na temat ewolucji Verfassungbeschwerde $\mathrm{w}$ niemieckim porządku prawnym.

Recenzowana monografia składa się z pięciu części ujętych w rozdziały oraz z wprowadzenia i zakończenia. Przy czym zakończenie, z uwagi na swoją zawartość merytoryczną oraz objętość, z powodzeniem mogłoby stanowić odrębny rozdział, choć jak można przypuszczać, nie pozwoliły na to względy wydawnicze. Pierwsze dwa rozdziały mają w zasadzie charakter wprowadzający, w kolejnych znajdziemy rzetelne omówienie zasadniczych obszarów ochrony skargowej. Dodatkową zaletą publikacji są załączniki zawierające tabele przedstawiające m.in. wpływ spraw, w tym skarg konstytucyjnych, do FTK w poszczególnych latach oraz sposób ich załatwienia. Szkoda, że wśród nich nie znalazło się zestawienie ukazujące, które wzorce kontroli wykorzystywane są najczęściej przez skarżących w procedurze skargi konstytucyjnej oraz w odniesieniu do których z nich FTK stwierdzał, że do naruszenia doszło.

W rozdziale I M. Derlatka podejmuje rozważania na temat pojęcia skargi konstytucyjnej, przedstawia genezę i rozwój instytucji skargi na kontynencie europejskim oraz wskazuje na rozmaitość rozwiązań przyjmowanych w tym zakresie w poszczególnych państwach. Ta zasadnicza część wywodu poprzedzona została dość obszernym wprowadzeniem na temat sądownictwa konstytucyjnego. Można mieć wątpliwość, czy do zrealizowania celu pracy było to rzeczywiście konieczne. Autorka wychodzi od genezy sądowej kontroli 
konstytucyjności w Stanach Zjednoczonych, ukazując zarazem różnicę między amerykańskim a europejskim modelem kontroli konstytucyjności. Następnie opisuje proces rozwoju sądownictwa konstytucyjnego w Europie oraz prezentuje zakres możliwych kompetencji przyznawanych trybunałom konstytucyjnym, eksponując zarazem tę najbardziej podstawową i uniwersalną, jaką jest kontrola zgodności prawa z konstytucją. W dalszej kolejności Autorka omawia skargę konstytucyjną jako jedną z kompetencji sądu konstytucyjnego oraz wprowadza do problematyki terminologicznej właściwej dla skargi poprzez wyszczególnienie istotnych jej elementów, tj. zakres podmiotowy, przedmiotowy, wzorzec kontroli, interes prawny, zasada subsydiarności czy też zasada selekcji. Przy czym udanym zabiegiem jest ukazanie powyższych elementów jako odróżniających kontrolę za pomocą skargi konstytucyjnej od abstrakcyjnej i konkretnej kontroli norm oraz ich usystematyzowanie. W publikacji właśnie te elementy, z pominięciem zakresu przedmiotowego, zaliczone zostały do cech wspólnych występujących w Europie skarg konstytucyjnych. Z kolei jako kryterium dyferencjacji skarg wskazano przede wszystkim na zakres przedmiotowy. M. Derlatka odniosła się także do podejmowanych w piśmiennictwie polskim i niemieckojęzycznym prób klasyfikacji skarg konstytucyjnych. Punktem wyjścia jest tu podział na szeroki (inaczej określany klasycznym) i wąski model skargi konstytucyjnej czy też w wersji zaproponowanej przez G. Brennera podział na ujęcie szersze skargi konstytucyjnej (rzeczywista skarga) oraz ujęcie węższe (skarga pozorna). W pełni podzielam pogląd, że podziałowi modeli skargi konstytucyjnej na wąski i szeroki nie można przypisać charakteru uniwersalnego (s. 55), choć dostrzec należy, że podział według tego kryterium ma pewien walor porządkujący. Nie oddaje on jednak faktycznych różnic między funkcjonującymi w państwach europejskich rozwiązaniami w zakresie skarg konstytucyjnych, a ponadto nie uwzględnia wielu zagadnień mających wpływ na ocenę efektywności skargi jako środka ochrony praw i wolności, a nie można przecież zapominać, że temu właśnie celowi miała ona służyć.

Rozdział II monografii służy wyeksponowaniu pozycji ustrojowej Federalnego Trybunału Konstytucyjnego. Omówiono w nim ewolucję niemieckiego sądu konstytucyjnego, scharakteryzowano jego kompetencje oraz organizację i sposób działania. Niewątpliwie jest to organ o rozbudowanych kompetencjach i o ugruntowanej pozycji w systemie organów władzy. Przy czym za trafne należy uznać stwierdzenie, że to właśnie skarga konstytu- 
cyjna stwarza niemieckiemu Trybunałowi niezwykle szerokie możliwości wpływania na kształtowanie praw jednostki oraz wypowiadania się w wielu ważkich sprawach o randze konstytucyjnej i politycznej (s. 82).

Rozdział III rozpoczyna właściwą część pracy, w której Autorka koncentruje się na analizie regulacji prawnej niemieckiej skargi konstytucyjnej pod kątem jej zakresu podmiotowego, przedmiotowego oraz dopuszczalnych wzorców kontroli. Za niezwykle interesujące należy uznać rozważania dotyczące zakresu podmiotowego, szczególnie w kwestii prawa do skargi zagranicznych osób prawnych oraz osób prawa publicznego. Zwłaszcza że w Polsce zagadnienie przyznania zdolności skargowej tym ostatnim podmiotom wywołuje kontrowersje. Nie mniej ciekawe jest również ukazanie problemu ustalenia granic kontroli trybunalskiej wobec działań sądów. Jest to niezwykle istotna kwestia we wszystkich tych systemach, w których w ramach skargi konstytucyjnej dopuszczono możliwość zaskarżania rozstrzygnięć sądowych. W piśmiennictwie podkreśla się, że trybunał konstytucyjny nie może przekształcić się w kolejną instancję sądową, stąd też podejmowane są próby określenia dopuszczalnych sfer kontroli konstytucyjności orzeczeń sądowych. Wskazuje się na przykład, że trybunał konstytucyjny powinien zajmować się wyłącznie zagadnieniami natury konstytucyjnej, pomijając te, którym takiego charakteru przypisać nie można, ponieważ dotyczą ściśle materii ustawowej. Rolą tego organu nie jest bowiem czuwanie nad prawidłowością stosowania ustaw zwykłych przez sądy, o ile nie ma to związku z ustawą zasadniczą. W rzeczywistości rozgraniczenie sfery konstytucyjności od sfery legalności jest bardzo trudne. Ponadto wobec znaczącej liczby skarg, w których zgłaszane są właśnie naruszenia wywołane przez sądy, rozstrzyganie o błędach tych ostatnich często staje się faktycznym przedmiotem aktywności sądu konstytucyjnego, a to z kolei wpływa na poszerzanie obszaru ingerencji trybunalskiej. Skala i rozmaity charakter spraw dotyczących „naruszeń sądowych” powodują trudności w ustaleniu stabilnych kryteriów kontroli orzeczeń sądowych. Dostrzega to również Autorka, zwracając uwagę, że płynność powyższych kryteriów, w świetle stale rozwijającej się wykładni Ustawy Zasadniczej i przenikaniu prawa konstytucyjnego do poszczególnych dziedzin prawa, pozostawia FTK stosunkowo duży margines swobody w ocenie działalności sądów, przez co naraża Trybunał na zarzut przekształcania się w sąd superrewizyjny (s. 126-129). 
W rozdziale IV przedstawione zostały przesłanki dopuszczalności skargi konstytucyjnej oraz procedura jej rozpatrywania (rozpoznania). Spośród omówionych tu przesłanek materialnych i formalnych na szczególną uwagę zasługują dwie - wymóg wykazania „istnienia zasadniczego prawnokonstytucyjnego znaczenia” oraz „szczególnie niekorzystnych skutków”, jakie mogłoby wywołać dla skarżącego nierozpoznanie skargi (\$93a ust. 2 ustawy o FTK). O ile pierwsza jest przejawem obiektywizacji skargi konstytucyjnej, o tyle druga odwołuje się do indywidualnej sytuacji skarżącego, a więc daje ona wyraz subiektywnej funkcji skargi. Pierwsza przesłanka stwarza szerokie możliwości selekcjonowania skarg. Dzięki niej pozostają poza zakresem zainteresowania Trybunału sprawy niewymagające wyjaśnienia problemu prawnokonstytucyjnego, nawet jeżeli wskazują na rzeczywiste naruszenie praw jednostki. Ocena, czy w danym przypadku występuje zagadnienie o zasadniczym konstytucyjnoprawnym znaczeniu należy do organu wstępnej kontroli. Przesłanka druga pozwala FTK interweniować w przypadkach szczególnie drastycznego naruszenia praw jednostki, nawet gdy interwencja ta nie przyniesie istotniejszych efektów dla rozwoju prawa konstytucyjnego i jego wykładni (s. 192). Z drugiej jednak strony zauważa się, że sposób jej sformułowania sprawia, że Trybunał ma również i w tym przypadku znaczne pole elastyczności dla dowolności selekcjonowania napływających skarg. Ma to sprzyjać rozwiązaniu problemu jego przeciążenia. W praktyce omawiana przesłanka jako uzasadniająca merytoryczne rozpoznanie skargi znajduje zastosowanie wyjątkowo. Problematykę poruszaną w tej części pracy trzeba uznać za kluczową dla oceny funkcjonalności niemieckiej instytucji. Przy nawet najszerszym zakresie przedmiotowym oraz podmiotowym skargi zbyt restrykcyjne wymogi mogą istotnie wpłynąć na faktyczny zakres ochrony skargowej. Z powyższych względów obserwacje poczynione w niniejszej publikacji na temat postępowania wstępnej kontroli oraz zasad selekcjonowania skarg przez FTK są pouczające i skłaniają do szerszej refleksji nad koniecznością poszukiwania optymalnych rozwiązań w celu zapewnienia skarżącym dostatecznych gwarancji w systemie środków ochrony prawnej zarówno w prawie krajowym, jak i międzynarodowym. W tej sferze istnieje potrzeba prowadzenia dalszych badań.

Zagadnienie skutków orzeczeń FTK zostało podjęte w rozdziale V. Złożoność konstrukcji niemieckiej skargi sprawia, że w zależności od rodzaju naruszenia orzeczenie Trybunału wywołać może różne skutki, stąd zasad- 
ne stało się ich wyodrębnienie na sytuacje, gdy naruszenie wynika z orzeczenia lub decyzji indywidualnej oraz gdy naruszenie spowodowane jest niekonstytucyjnością ustawy. Dla polskiego czytelnika interesujący będzie ten pierwszy przypadek. Jeżeli skarga konstytucyjna zwrócona jest bezpośrednio przeciwko indywidualnemu rozstrzygnięciu, orzeczenie FTK będzie miało zazwyczaj skutek kasacyjny, ale - jak się podkreśla - nie reformacyjny. Co oznacza, że Trybunał, uchylając zaskarżone orzeczenie (decyzję), nie powinien rozstrzygać sprawy co do meritum, ani nakładać dodatkowych obowiązków na organy władzy publicznej, tj. przyznanie odszkodowania czy też zobowiązanie organu do określonego działania (s. 244). W praktyce bywało jednak inaczej. Jest to przejaw wysunięcia na plan pierwszy funkcji subiektywnej skargi, jako że w takim wypadku Trybunał przyznaje ochronę określonej osobie w konkretnej sytuacji, realizując tym samym interes indywidualny skarżącego.

Za wartościowe i dopełniające względem poruszanej w pracy problematyki należy uznać zakończenie. Jest to na pewno jedna z ciekawszych części pracy. Autorka przedstawiła tu obraz faktycznie istniejącego w Niemczech modelu skargi konstytucyjnej, przywołując informacje na temat liczby rozpoznanych skarg w ostatnich latach. Pozwoliło to ukazać ewolucję podejścia do funkcji skargi konstytucyjnej i znaczenie tego instrumentu dla rozwoju całego systemu niemieckiej konstytucji, jak i konstytucjonalizacji szczegółowych dziedzin prawa. W dużej mierze podzielam przedstawione w tej części pracy wnioski wynikające z porównania polskiej i niemieckiej skargi konstytucyjnej, choć M. Derlatka nie przekonała mnie, że niezależnie od przyjętego modelu skargi konstytucyjnej, realizuje się ona na pierwszym miejscu w funkcji obiektywnej. Obiektywizacja skargi została bowiem niejako wymuszona ze względów prakseologicznych, a w założeniu skarga konstytucyjna służyć miała przede wszystkim ochronie konstytucyjnych praw i wolności jednostki.

W dalszej części recenzji odniosę się do wybranych problemów poruszonych w publikacji, które w moim przekonaniu wymagają szerszego komentarza.

Dokonując klasyfikacji skarg, Autorka odnosi się do hiszpańskiej skargi konstytucyjnej, którą obok skargi belgijskiej uznaje za skargę przysługującą tylko co do części konstytucyjnych praw. Następnie stwierdza, że przyjęte w Hiszpanii ograniczenia mają stosunkowo szeroki charakter także 
w rzeczywistości (s. 46). Stwierdzenie to wymaga jednak uzupełnienia. Konstytucja Hiszpanii w art. 53 ust. 2 Konstytucji stanowi, że ochrona w drodze skargi konstytucyjnej przysługuje w razie naruszenia praw określonych w art. 14, art. 30 ust. 2 oraz w sekcji 1 rozdziału II (art. 15-29). Do katalogu praw chronionych należą zatem prawa wyraźnie wymienione w Konstytucji. Nie oznacza to, że prawa, które nie zostały expressis verbis wyrażone we wskazanych przepisach nie mogą stanowić podstawy hiszpańskiej skargi konstytucyjnej. Po pierwsze, zarówno w doktrynie, jak i w orzecznictwie hiszpańskiego Trybunału Konstytucyjnego dominuje opinia, że niektóre z praw, o których mowa w art. 53 ust. 2 Konstytucji, mieszczą w sobie szereg gwarancji, z których każda może stanowić odrębne prawo lub wolność. Po drugie, hiszpański Trybunał, kierując się przede wszystkim gwarancyjnym charakterem skargi, niejednokrotnie wykraczał poza tak wyznaczone granice ochrony skargowej, posługując się koncepcją tzw. praw pochodnych. Pozwoliło to na objęcie ochroną także praw niewysłowionych w art. 53 ust. 2, ale pozostających w nierozerwalnym związku z prawami chronionymi. Podstawę wyodrębniania praw pochodnych stanowiły inne przepisy Konstytucji, a niekiedy nawet przepisy ustawowe. Trybunał poszukiwał powiązania między prawem podlegającym ochronie a innym prawem bądź też wzbogacał treść tego pierwszego o inne elementy i w ten sposób poszerzał zakres ochrony skargowej. Przykładowo organ ten powiązał chronione prawo do zrzeszania się (art. 22 Konstytucji) z art. 6, w którym mowa o partiach politycznych, i na tej podstawie przyznał ochronę prawu do zrzeszania się w partie polityczne. Z kolei prawo do zrzeszania się w związki zawodowe (art. 28 konstytucji) rozciągnął na prawo do zbiorowych rokowań i negocjacji oraz do rozstrzygania sporów zbiorowych (art. 37 konstytucji). Znaczną aktywność hiszpańskiego Trybunału w kwestii poszerzania zakresu ochrony można zaobserwować w odniesieniu do prawa do sądu (art. 24 konstytucji) oraz zasady równości (art. 14 konstytucji). Prawo do sądu powiązane zostało z zasadami określonymi w tytule VI Konstytucji (art. 118, 119, 120 ust. 3).

Jeżeli przyjąć pogląd, że skarga konstytucyjna jest „procedurą niezwykle pożądaną i odgrywającą szczególną rolę w ochronie praw i wolności jednostki" (s. 57), to nie bez znaczenia będzie ustalenie, w jakim stopniu ochrona ta jest realizowana. Skoro według upowszechnionej w naszym piśmiennictwie definicji skarga konstytucyjna jest instrumentem służącym jednostce w razie naruszenia jej konstytucyjnych praw i wolności, umożliwiającym bez- 
pośredni dostęp do sądu konstytucyjnego, to powstaje pytanie, na czym ma polegać udzielana skarżącemu ochrona. Można stawiać również kolejne pytania o zakres udzielanej ochrony, o rolę sądu konstytucyjnego oraz o to, co może zyskać skarżący dzięki swojej aktywności w postaci wniesienia skargi.

Zakres ochrony skargowej jest zróżnicowany i zależy od koncepcji instytucji skargi uznanej i utrwalonej w danym systemie prawnym. Skarga może służyć przeciwdziałaniu konkretnemu naruszeniu konstytucyjnego prawa lub wolności i łagodzeniu skutków tego naruszenia, zwłaszcza gdy w skardze przeważa element subiektywny - takie założenie przez długi czas przyjmowano na przykład w Hiszpanii. Skarga może też być ukierunkowana przede wszystkim na zapewnienie spójności systemu prawnego oraz nadrzędności konstytucji. Zasadniczo więc podejście do skargi konstytucyjnej uzależnione jest od określenia jej podstawowej funkcji. W piśmiennictwie wskazuje się przeważnie na dwie istotne funkcje skargi konstytucyjnej: funkcję podmiotową (zwaną subiektywną) oraz funkcję przedmiotową (określaną jako obiektywna). Funkcja podmiotowa, uznawana za pierwotną funkcję skargi, sprawia, że w skardze należy przede wszystkim widzieć instrument gwarancyjny, umożliwiający jednostce realizację przysługujących jej uprawnień. $\mathrm{Z}$ kolei funkcja przedmiotowa powoduje, że interes skarżącego przestaje mieć pierwszorzędne znaczenie. Skarga staje się wówczas środkiem kształtowania sędziowskiej wykładni konstytucji i rozstrzygania doniosłych problemów konstytucyjnych czy też, inaczej mówiąc, „wyjaśnianiem i rozwijaniem obiektywnie istniejącego prawa konstytucyjnego”.

Dla zapewnienia funkcji podmiotowej skargi wprowadza się rozwiązania umożliwiające skarżącemu uzyskanie żądanej przez niego ochrony w zakresie, w jakim wymaga tego naruszone prawo. Ma tu znaczenie zarówno dostępność skargi dla skarżących (warunki jej wniesienia, tj. wymogi formalne), ale również ocena szans powodzenia na uzyskanie merytorycznego rozstrzygnięcia, a także ewentualne jego skutki na sytuację skarżącego. Jako decydujące w tym względzie można wskazać takie czynniki jak: relatywnie niski stopień sformalizowania postępowania skargowego, brak przymusu adwokacko-radcowskiego, bezpłatność, możliwość przywrócenia terminu sprecyzowane przesłanki dopuszczalności skargi, możliwość wstrzymania wykonania zaskarżonego aktu władzy publicznej (suspensywność) oraz efekt kasacyjny i kompensacyjny orzeczenia rozstrzygającego skargę. Z kolei funkcji przedmiotowej przypisuje się zorientowanie postępowania w spra- 
wie skargi konstytucyjnej na ogólną ochronę konstytucji. W takim wypadku działalność trybunału konstytucyjnego koncentruje się na badaniu, czy określone działanie (zaniechanie) władzy publicznej (ustawodawczej, wykonawczej, sądowniczej) pozostaje w zgodzie z konstytucyjnym porządkiem prawnym. Skarga służyć ma bowiem wyeliminowaniu z obrotu prawnego stwierdzonej „sprzeczności” poprzez uznanie, że dany przepis lub praktyka jego stosowania są niezgodne z konstytucją.

Pożądane jest, aby skarga spełniała obie funkcje w równym stopniu, w praktyce jednak okazuje się, że funkcje te są sobie przeciwstawiane. Doświadczenia państw europejskich - takich jak: Niemcy, Hiszpania, Czechy - w których występował najbardziej zbliżony model skargi konstytucyjnej cechujący się uniwersalnym zakresem ochrony skargowej, uzasadniają twierdzenie, że obecnie odchodzi się od funkcji podmiotowej jako funkcji pierwszoplanowej czy też od jej tradycyjnego rozumienia - nie zawsze zresztą konsekwentnie. Skarga służyć ma nie tyle realizacji indywidualnego interesu skarżącego, co różnie pojmowanym interesom ogólnym. Kształt postępowania skargowego, a tym samym konstrukcja skargi zostaje ukierunkowana na realizację funkcji przedmiotowej. Przejawia się to w ograniczaniu dostępności skargi poprzez wprowadzanie rygorystycznych wymogów formalnych, zaostrzanie kryteriów jej dopuszczalności oraz w wyposażeniu trybunałów konstytucyjnych w możliwość doboru skarg o „zasadniczym znaczeniu konstytucyjnym". Wydaje się jednak, że obiektywizacja skargi konstytucyjnej jest nieuniknionym etapem na drodze rozwoju tej instytucji. W odniesieniu do niemieckiej skargi konstytucyjnej dostrzega to zjawisko również Autorka recenzowanej pracy, wskazując, że wcześniej w kształtowaniu modelu niemieckiej instytucji akcent padał przede wszystkim na ochronę subiektywnego interesu jednostki, a dopiero praktyka orzecznicza zrewidowała te założenia, dokonując jego przesunięcia na ochronę samej konstytucji (s. 10, 163, 210, 229-230, 279, 304).

Przykład niemieckiej skargi konstytucyjnej ukazuje pewną sprzeczność tkwiącą u założeń jej konstrukcji. Sprzeczność, czy inaczej brak konsekwencji przy kształtowaniu niektórych elementów skargi, dobrze ilustruje niniejsze opracowanie. Z jednej strony niemiecka skarga konstytucyjna określana jest jako najbardziej wszechstronna pod względem zakresu ochrony skargowej, uznawana przecież za skargę o szerokim zakresie przedmiotowym, podmiotowym oraz szerokiej podstawie, przy czym sam FTK w drodze wykład- 
ni funkcjonalnej materialnie ten model rozszerzył (s. 159). Z drugiej strony, na skutek tak szeroko zakreślonej ochrony skargowej, a przez to konieczności rozwiązania problemu nadmiaru skarg i zapewnienia efektywności działania trybunału, organ ten ma bardzo szerokie możliwości selekcjonowania spraw, które zmuszony jest wykorzystywać (s. 188, 209-210). W ten sposób realną dostępność skargi można ocenić jako wysoce ograniczoną, co powoduje, że niemiecka skarga konstytucyjna stała się mniej efektywnym środkiem ochrony z punktu widzenia interesu skarżących. W tej sytuacji, dostrzegając złożoność problemu oraz uznając proces obiektywizacji skargi za nieunikniony, nie pozostaje czytelnikowi nic innego, jak podzielić - mimo pewnych oporów - optymizm Autorki i ufać, że niemiecki Trybunał korzysta $\mathrm{z}$ przywileju doboru spraw „niezwykle rozsądnie, wybierając z tysięcy napływających skarg faktycznie te o najbardziej istotnym charakterze i największym ciężarze gatunkowym" (s. 280).

Ukazanie w szerszej perspektywie złożoności problematyki niemieckiej skargi konstytucyjnej zawarte w recenzowanej książce zasługuje na uznanie. Monografia jest ciekawym i wartościowym opracowaniem, poruszającym teoretyczne i praktyczne aspekty funkcjonującego w Niemczech modelu ochrony skargowej. Ponadto publikacja ta stanowi ważny głos w dyskusji nad ewentualną reformą polskich rozwiązań prawnych. Warto zatem polecić jej lekturę.

Marta Kłopocka-Jasińska (Wyższa Szkoła Menedżerska w Legnicy) 